\title{
English Abstracts
}

Thomas Koch / Thomas Zerback: Repetition and Truth. On the Impact of Repeated Political Slogans on People's Perception of Credibility (Wiederholung und Wahrheit. Wie die mehrmalige Präsentation politischer Slogans die Einschätzung ihrer Glaubwürdigkeit beeinflusst), pp. 487-504

The 'truth-effect' is well-known in perceptual psychology. It implies that humans tend to believe in things they hear repeatedly. Our research is the first to investigate this trutheffect in a political context, using an experimental design. Various political slogans from political campaigns, for instance, were presented to participants, while we systematically manipulated the extent of repetition. As expected, we discovered a relationship between the number of repetitions and participants' credibility-ratings. However, the effect was limited to individuals with issue-related knowledge. Furthermore, the data suggests an inverted U-shaped relationship between repetition and credibility: While credibility ratings increased at lower repetition levels, they decreased when the statement was presented too often.

Keywords: truth-effect, political communication, political advertisement, election poster, repetition effects, online-experiment

Monika Taddicken / Irene Neverla: Climate Change from the Perspective of Media Consumers. A Multifactor Effects Model of Media Experiences with Regard to the Complex Knowledge Domain Climate Change (Klimawandel aus Sicht der Mediennutzer. Multifaktorielles Wirkungsmodell der Medienerfahrung zur komplexen Wissensdomäne Klimawandel), pp. 505-525

Climate change is one of today's big issues on the media agenda. While media coverage has been well-researched by communication scholars, there is a knowledge gap concerning the audience's perspective. What impact media coverage really has on recipients' (and citizens') perception of climate change has hardly been analysed. Hence, this paper focuses on this issue. A theory-based effects model of media experiences regarding complex knowledge domains - here: climate change - is presented, which incorporates the dynamic-transactional perspective. Following this, empirical results from a representative online survey are analysed and embedded in this model as a case study. The findings indicate that the consumption of media content is primarily related to the state of knowledge regarding the topic, as well as to the disposition to take responsibility and action with regard to climate change. The affective evaluation of problem awareness, by contrast, does not appear to be connected to media usage, while individual characteristics, such as environmental awareness, are more relevant. Moreover, the results show that the social environment is a significant aspect shaping the individual attitude towards climate change.

Keywords: media reception, media effects, dynamic transactional approach, climate change, environmental awareness, online survey 
Elke Weissensteiner / Dominik Leiner: Researching Facebook. A Review of Studies on Social Network Sites (Facebook in der Wissenschaft. Forschung zu sozialen Onlinenetzwerken), pp. 526-544

In recent years, Facebook and Myspace have evoked major changes to the Internet: social Network Sites (SNS) have shifted young adults' social interaction and communication practices towards Web 2.0. This paper presents a review of the research on SNS. Based on the relevant studies' research questions, we identified at least six major topis within SNS research: users' characteristics, adoption motives, social capital, self-expression, profile perception and privacy.

Keywords: literature review, SNS, social web, Facebook, Myspace

Michael Scharkow: Combining Manual and Automated Content Analysis through Automatic Learning (Zur Verknüpfung manueller und automatischer Inhaltsanalyse durch maschinelles Lernen), pp. 545-562

Although computer-assisted methods of content analysis have many advantages when processing large amounts of text, automatic coding is still fairly rare in communication research. This is often due to the fact that rule or dictionary-based coding methods used in applied research are inherently incompatible to traditional manual coding. This paper introduces a recent approach to automatic content analysis, which is based on supervised automatic learning. By combining manual coding of training data and subsequent automatic classification, supervised learning is an attractive option for large-scale analyses of digital content. After describing the conceptual and algorithmic basics of supervised text classification, I illustrate its use in a thematic analysis of German online news.

Keywords: methods, content analysis, machine learning, bag-of-words

Michael Meyen / Maria Löblich: Gerhard Maletzke. A Story of Success and Failure in Communication Science (Gerhard Maletzke. Eine Geschichte von Erfolg und Misserfolg in der Kommunikationswissenschaft), pp. 563-580

Communication scholars traditionally have ambivalent feelings towards Gerhard Maletzke, a classic author in the field. His book "Psychologie der Massenkommunikation" is an indispensable part of teaching, however, Gerhard Maletzke was never appointed professor of communication science. This paper deals with the explanation of this antagonism. From a sociology of science perspective, we analyse the relationship of biography, work and the discipline's structures. Apart from Maletzke's academic work and biographical sources, an in-depth interview about his life and interviews with colleagues are analysed. The findings show that the success of "Psychologie der Massenkommunikation" can be explained by the re-orientation of the discipline beginning in the 1960s. Furthermore, Gerhard Maletzke always seems to have been in the wrong place at the wrong time. He did not have the 'right' background in psychology and in communication science; he lacked a strong mentor and the right political party membership book. Without professorship and without the help of pupils he had no chance to extend his work. This paper shows the significance of institutional factors to scientific work.

Keywords: Psychologie der Massenkommunikation, communication models, communication science history, biography 